\title{
The reproductive biology of the early-divergent genus Anaxagorea [Annonaceae], and its significance for the evolutionary development of the family
}

\author{
Gerhard Gottsberger ${ }^{1}$
}

Received: November 26, 2015

Accepted: February 11, 2016

\begin{abstract}
Data of six studied Neotropical Anaxagorea species are analyzed and discussed with respect to the population structure, flowering phenology, flower morphology, anthesis, scent emission, thermogenesis, floral visitors, breeding system, fruit-set and seed dispersal. The probably reason for the patchy distribution of small populations of Anaxagorea species within lowland tropical forests is given. A novel explanation of the functional significance of ruminate endosperm is presented. Flowering of the species follows either the annual or the continuous flowering pattern. All studied species have diurnal, two-day lasting, protogynous anthesis; several species have thermogenic flowers. Self-compatibility appears to be the prevailing reproductive system in the genus. However, there is a strong tendency for effecting cross-pollination. Floral scent of Anaxagorea species contains fruit-like components, and the pollinators, primarily Nitidulidae (Colopterus spp.) are attracted by deceit. Strong scenting pollination chambers occur also in most other cantharophilous Annonaceae. Novel floral developments are apparent mainly in fly-, cockroach- and bee-pollinated Annonaceae, which have patterns different from cantharophilous species and exhibit open flowers with reflexed petals, which allow their pollinators to reach and touch the reproductive organs.
\end{abstract}

Keywords: Anaxagorea, pollination, reproductive biology, radiation and diversification of Annonaceae, reproductive systems, ruminate endosperm, seed dispersal

\section{Introduction}

With about 2300-2500 species, the family Annonaceae is the most species-rich group of the Magnoliales and, together with the Piperaceae (Piperales), Lauraceae (Laurales) and Araceae (Alismatales, basal monocots), the Annonaceae belong to the largest families of the basal angiosperms (e.g. Bremer et al. 2009; Smith et al. 2010; Zeng et al. 2014). A few basal angiosperms belong to relictual families that have only one or a few species, while most other families contain at the maximum a few hundred species. Thus, the speciesrich Annonaceae is one of the few families of the basal angiosperms having capacity for a broader diversification and ecological radiation.

Anaxagorea is the basal genus of the Annonaceae. The consideration that Anaxagorea is the sister group of the rest of the Annonaceae is based on various morphological and molecular cladistic analyses of the family (Doyle \& Le Thomas 1994; 1996; Zuilen \& Koek-Noorman 1997;

\footnotetext{
${ }^{1}$ Botanischer Garten, Universität Ulm, Hans-Krebs-Weg, D-89081 Ulm, Germany. gerhard.gottsberger@uni-ulm.de
} 
Doyle et al. 2000; Sauquet et al. 2003; Scharaschkin \& Doyle 2005; 2006). Recently, the monophyly of Annonaceae and the sister group relationship between Anaxagorea (subfamily Anaxagoreoideae) and the remaining Annonaceae was supported in several analyses (Chatrou et al. 2012). The basal position of Anaxagorea in Annonaceae is indicated by several distinctive, putatively ancestral morphological character states, that are also found in the closest outgroups of Annonaceae, especially in Eupomatia (Eupomatiaceae), Degeneria (Degeneriaceae) and Galbulimima (Himantandraceae), for example, the stamens are laminar, there are inner staminodes, the pollen is granular and monosulcate, and species have an adaxial plate of vascular tissue in the leaf midrib (Maas \& Westra 1984; 1985; Doyle \& Le Thomas 1994; 1996; Scharaschkin \& Doyle 2005; 2006) .

The genus comprises 30 species (Maas \& Westra 1984; 1985; Maas et al. 1986; Chatrou et al. 2012) which have a disjunct distribution in the Neotropics and in tropical Asia. Most species occur in South and Central America, ranging from Brazil to Guatemala. A few species are exclusively Central American (e.g. A. guatemalensis and A. panamensis). The four Asian species (A. borneensis, $A$. javanica, $A$. luzonensis and $A$. radiata) range from Sri Lanka to the Philippines and Indonesia (Maas \& Westra 1984; 1985; Maas et al. 1986; Berry et al. 1999). The Neotropical/ Asian disjunct distribution pattern of Anaxagorea is unique, insofar as most other disjunct genera in the Annonaceae have Asian/African disjunctions; another case is Xylopia which is pantropical, occurring in the Neotropics as well as in Africa and Asia (Maas \& Westra 1984; Kessler 1993).

The combined morphological and molecular data indicate that the South American species Anaxagorea prinoides is sister of the rest of the genus, followed by a clade of three other South American species (A. inundata, A. angustifolia, A. rheophyta). The Brazilian coastal Atlantic forest species, A. sylvatica, is sister of the large clade containing the Asian species, the Central American species, and the core South American clade. Thus, Anaxagorea apparently has a basal position of a South American group and a sequential branching of the Asian and Central American clades (Scharaschkin \& Doyle 2005). A cladogram shows the phylogenetic relationships within Anaxagorea and indicates the biogeographic distribution of species (Fig. 1).

Reviewing floral characters and the reproductive ecology of Anaxagorea is not only interesting for understanding functional flower evolution and diversification of the genus alone, but probably is also a means to throw light on some developments of the family Annonaceae and its capacity of morphological and ecological radiation.

\section{Materials and methods}

The reproductive biology was studied in six Neotropical Anaxagorea St.Hil. species. The distribution of the South
American A. prinoides (Dunal) A. DC. is restricted to the Guianas and the Brazilian Amazonian States Amapá and Pará (Maas \& Westra 1985). The species was studied in the Nouragues Natural Reserve $\left(4^{\circ} 5^{\prime} \mathrm{N}, 52^{\circ} 41^{\prime} \mathrm{W}\right)$ in French Guiana in an almost pristine tropical lowland forest (Teichert et al. 2011). The two South American species, A. manausensis Timmermann and A. brevipes Benth., as well as the South American/Central American A. phaeocarpa Martius were all studied in Central Amazonia in Brazil, in the surroundings of Manaus, either in the natural forest reserves of the Reserva Ducke or the Campus of the Universidade de Manaus (Webber \& Gottsberger 1994; Webber 1996; Jürgens et al. 2000), The South American/ Central American A. crassipetala Hemsley was studied in forests at the Organization for Tropical Studies field station at La Selva, Costa Rica (Armstrong \& Marsh 1997; Collier \& Armstrong 2009), Finally, the widely distributed South American/Central American species A. dolichocarpa Sprague \& Sandw. was studied at two places, in Guyana, at the Tropenbos field station Mabura Hill (Maas-van de Kamer 1993) and in Brazil (Braun \& Gottsberger 2011, 2012). The preliminary results on $A$. dolichocarpa from Guyana obtained from mainly one tree are largely congruent with the results obtained in Brazil. Field research on this species in Brazil covered nearly one year and was conducted in Atlantic forest fragments of the São José sugarcane plantation (USJ) in the municipality of Igarassu, Pernambuco State, northeastern Brazil $\left(07^{\circ} 41^{\prime}-07^{\circ} 54^{\prime} \mathrm{S}, 34^{\circ} 54^{\prime}-35^{\circ} 05 \mathrm{~W}\right)$.

The extensive methods of studies and analyses of the six species with respect to the population structure, flowering phenology, floral morphology, anthesis, floral visitors, thermogenesis, floral scent, breeding system, fruit set, seed dispersal and germination, are all indicated and elaborated in the papers cited above and thus the interested reader of this review is referred to these references.

\section{Population structure, seed dispersal and seedling growth}

Anaxagorea is mainly a lowland forest genus. Most species of the genus occur at altitudes between 0-1000 m. Apparently, only few species can grow above $1000 \mathrm{~m}$, e.g. A. dolichocarpa and A. acuminate St.Hil., which have been collected up to $1300 \mathrm{~m}$. Anaxagorea petiolata R.E.Fr. reaches the highest altitudes; this species has been found between 400-1500 m (Maas \& Westra 1984).

The investigated species are all small understory treelets or small trees with low diameter at breast height (dbh). The height of the six species studied ranged from 1.7-4.5 m and a dbh of 0.5 to $3.5 \mathrm{~cm}$ of adult trees in $A$. prinoides, the smallest species investigated, to $10-12 \mathrm{~m}$ and about 6-10 $\mathrm{cm}$ dbh in the largest species, A. dolichocarpa (Tab. 1). The smallest sizes reported by Maas \& Westra (1984) are for A. luzonensis (mostly 0.3-1.5 m tall) and for A. floribunda 


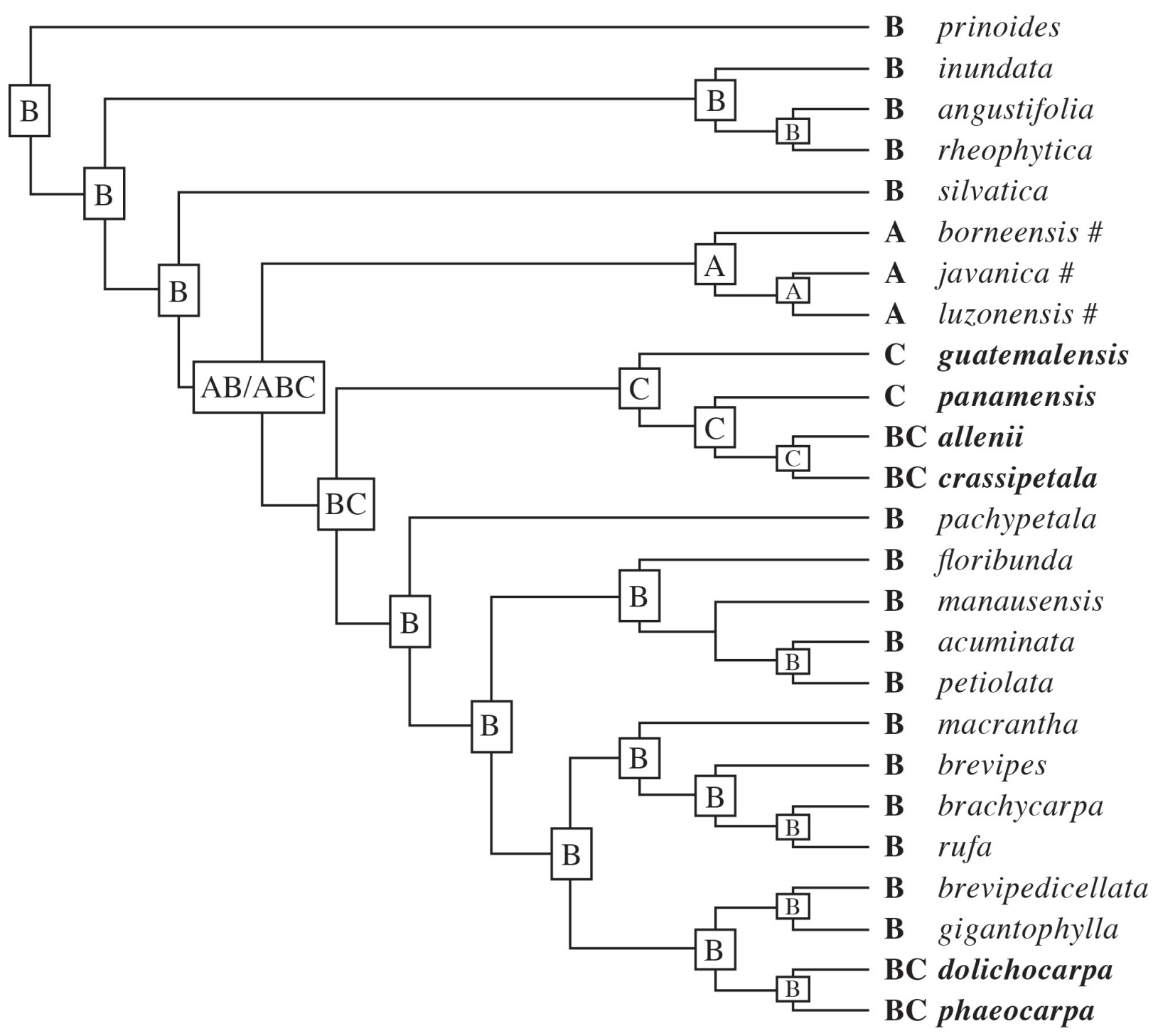

Figure 1. Phylogenetic tree of Anaxagorea, obtained from combined morphological and molecular data sets, with results of ancestral areas and biogeographic distribution of species. Central American species are in bold, Asian species are indicated by the symbol \#, and the remaining species are South American. A = Asia, B = South America, C= Central America (From Scharaschkin \& Doyle 2005).

with ca. $1 \mathrm{~m}$ height. They also mention that a height over $15 \mathrm{~m}$ is attained only exceptionally in Anaxagorea species.

As far as observed, the populations of the species have a patchy distribution (Tab. 1). In A. prinoides the small patchy isolated populations or plant groups consisted of 22 trees or less. The population under study extended over 0.03 ha. In this species, the mean distance between the nearest conspecific neighboring trees in the studied population was about $1.6 \mathrm{~m}$ (Teichert et al. 2011). These neighborhood distances were larger in A. crassipetala $(3.2 \mathrm{~m}$ ) (Armstrong \& Marsh 1997) and ranged from 9.1 to $13.6 \mathrm{~m}$ in the three species investigated in Manaus (Webber 1996). Already Maas \& Westra (1984) and others noted the occurrence of individuals of Anaxagorea in dense groups. Seed dispersal has been indicated to be responsible for the formation of patchy distributed, low numbers of isolated individuals within a forest. Seeds of Anaxagorea species are dispersed ballistically (e.g. Morawetz 1984; Armstrong \& Marsh 1997; Teichert 2008; Braun 2010). The autochorous, ballistic seed dispersal in Anaxagorea is more a short distance dispersal mode and differs from the dispersal of other Annonaceae, which is by mammals, birds, lizards and even fish (Gottsberger 1970; 1978), and covers much larger distances. In Anaxagorea, the seeds are ejected at a maximum of 5-7 $\mathrm{m}$ distance from the mother trees.

In A. prinoides and other Anaxagorea species, the light green, yellow, brown to reddish apocarpous fruits consist of several club-shaped carpels (fruitlets) born on stipes (Fig. 2A). Each ripe carpel contains two hard, black, shiny seeds, which are tightly pressed together (Fig. 2B). The distal part of the carpels has a thickened wall, which increasingly presses against the convex sides of the two smooth seeds during 
Table 1. Geographical distribution, population structure, tree size (total height and diameter at breast height=dbh), flowering period, flowering mode, and floral traits of the six investigated Anaxagorea species (data compiled from the authors given in the text).

\begin{tabular}{|c|c|c|c|c|c|c|}
\hline & A. prinoides & A. manausensis & A. brevipes & A. phaeocarpa & A. crassipetala & A. dolichocarpa \\
\hline Geogr. distribution & B & B & B & $\mathrm{BC}$ & $\mathrm{BC}$ & $\mathrm{BC}$ \\
\hline Population structure & $\begin{array}{l}\text { patchy } \\
0.03 \text { ha or less }\end{array}$ & not investigated & not investigated & not investigated & patchy & patchy \\
\hline Tree height $[\mathrm{m}]$ & $1.7-4.5$ & $6-9$ & $3.5-9$ & $3.5-9$ & $4-10$ & up to $10-12$ \\
\hline Tree dbh $[\mathrm{cm}]$ & $0.5-3.5$ & $5.9-10.1$ & $3.6-12.3$ & $2.4-6.4$ & $1.5-8.8$ & $6-10$ \\
\hline $\begin{array}{l}\text { Flowering period } \\
\text { Flowering mode } \\
\end{array}$ & $\begin{array}{l}\text { Sept-Oct } \\
\text { "annual" }\end{array}$ & $\begin{array}{l}\text { Sept-Dec } \\
\text { "annual" }\end{array}$ & $\begin{array}{l}\text { Sept-Dec } \\
\text { "annual" }\end{array}$ & $\begin{array}{l}\text { perennial } \\
\text { "continuous" }\end{array}$ & $\begin{array}{l}\text { Oct-Dec (?) } \\
\text { “annual" }\end{array}$ & $\begin{array}{l}\text { perennial } \\
\text { "continuous" }\end{array}$ \\
\hline $\begin{array}{l}\text { Petal size }[\mathrm{mm}]: \text { I x b } \\
\text { Outer petals } \\
\text { Inner petals }\end{array}$ & $\begin{array}{l}11 \times 5 \\
11 \times 4.5\end{array}$ & $\begin{array}{l}9-14 \times 12-16 \\
\text { same size }\end{array}$ & $\begin{array}{l}18-23 \times 16-21 \\
\text { same size }\end{array}$ & $\begin{array}{l}19-24 \times 10-12 \\
\text { same size }\end{array}$ & $\begin{array}{l}9-22 \times 3.5-6 \\
6-14 \times 2-3\end{array}$ & $\begin{array}{l}13-14 \times 6.6-8.7 \\
11.3-12.5 \times 5.8-6.4\end{array}$ \\
\hline Stamen no. & $14 \pm 2$ & $24-26$ & $97-100$ & $35-85$ & $42-60$ & $33-45$ \\
\hline Staminode no. & $11 \pm 2$ & ca. 10 & ca. $30-45$ & ca. $20-45$ & ca. $10-20$ & $12-18$ \\
\hline Carpel no. & $12 \pm 2$ & $18-23$ & $10-25$ & $15-45$ & 18 & $9-15(-21)$ \\
\hline
\end{tabular}

$\mathrm{B}=$ South America, $\mathrm{C}=$ Central America; flowering mode after Newstrom et al. 1994; petal size $1 \mathrm{x} \mathrm{b}=$ length $\mathrm{x}$ breath.
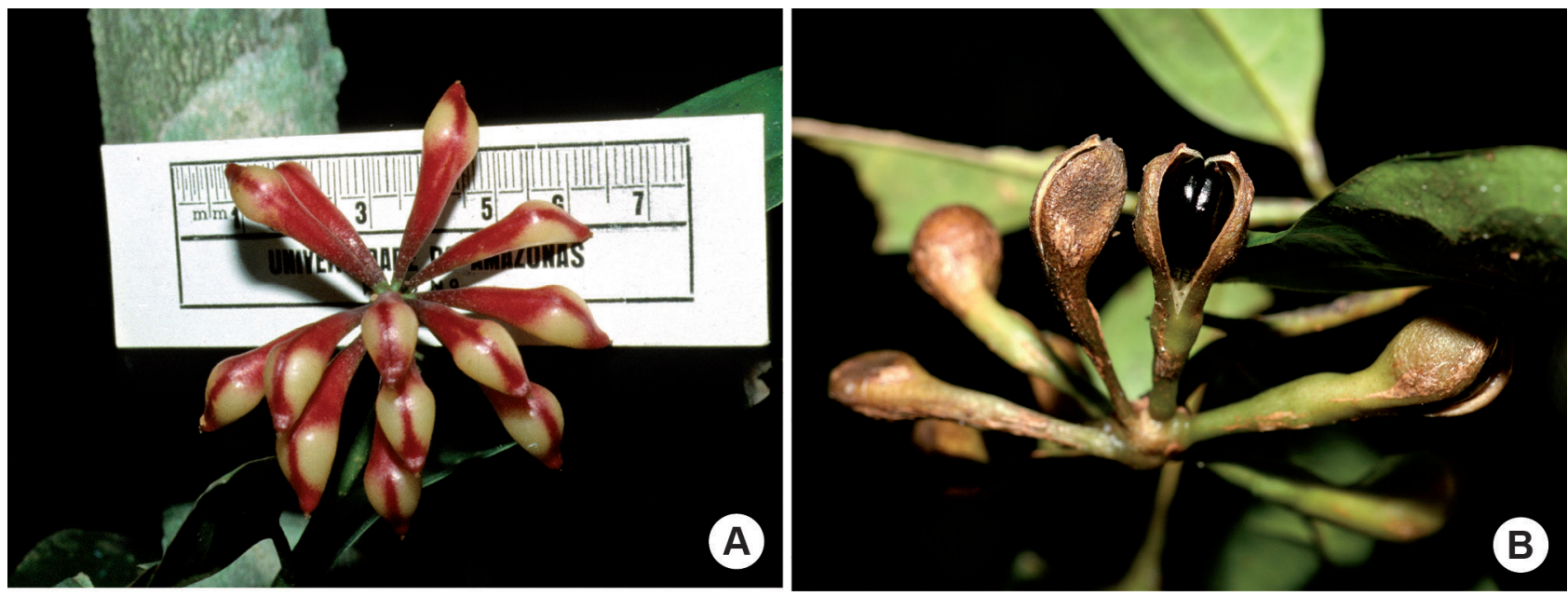

Figure 2. Fruits and seeds of Anaxagorea. A. Apocarpous, unripe fruit of A. brevipes composed of several still closed, club-shaped carpels (fruitlets, ca. $35 \mathrm{~mm}$ long). Photo credit A.C. Webber. B. Apocarpous fruit of A. prinoides with ripening and ventrally opening carpels (ca. $25 \mathrm{~mm}$ long). One carpel shows the two black seeds with their outer convex side and their inner flat side. The seeds lie with the flat sides closely appressed. Photo credit H. Teichert.

desiccation, until reaching a point of pressure that forces the seeds out explosively. The process could be observed in $A$. dolichocarpa with ripe fruitlets (with leathery walls, opening at the ventral suture), which ejected both seeds of a carpel, simultaneously with high speed, and up to a distance of ca. $5 \mathrm{~m}$ (Braun 2010). However, the seed dispersal mode does not explain well why there are small isolated populations or plant groups. Even in ballistic seed dispersal, slowly but steadily expanding plant groups should merge with each other along the years. Thus, there must be further reasons for the maintenance of small and isolated plant groups within the forests. One possibility is that such tiny and thin trees like Anaxagorea are suffering from tree- and branchfall and are thus often damaged or even killed. It is further possible that germination of seeds or, more importantly, the seedling growth in Anaxagorea is only possible in gaps, which would explain their patchy, isolated distribution within forests. Both processes probably work in concert. The Anaxagorea plant groups growing up in luminous gaps in grown tall forest may later be weakened by the increasing shade, and finally damaged and eventually destroyed by falling branches and trunks of tall trees, while new plant groups grow up in new gaps.

The seeds of Anaxagorea have a ruminate endosperm 
The reproductive biology of the early-divergent genus Anaxagorea [Annonaceae],

and its significance for the evolutionary development of the family

(Fig. 3A) of the irregular type, which is a hollow, papery type (Corner 1949), as opposed to the more common solid lamelliform and spiniform ruminations. Such irregular ruminate endosperm type also occurs in the outgroups Eupomatia and Degeneria, and is ancestral in Annonaceae, occurring not only in Anaxagorea but also in the subfamily Ambavioideae (Scharaschkin \& Doyle 2006; Pirie \& Doyle 2012). Although seeds with ruminate endosperm are known from 58 plant families, the function of this morphological trait has not been elucidated (Bayer \& Appel 1996). The
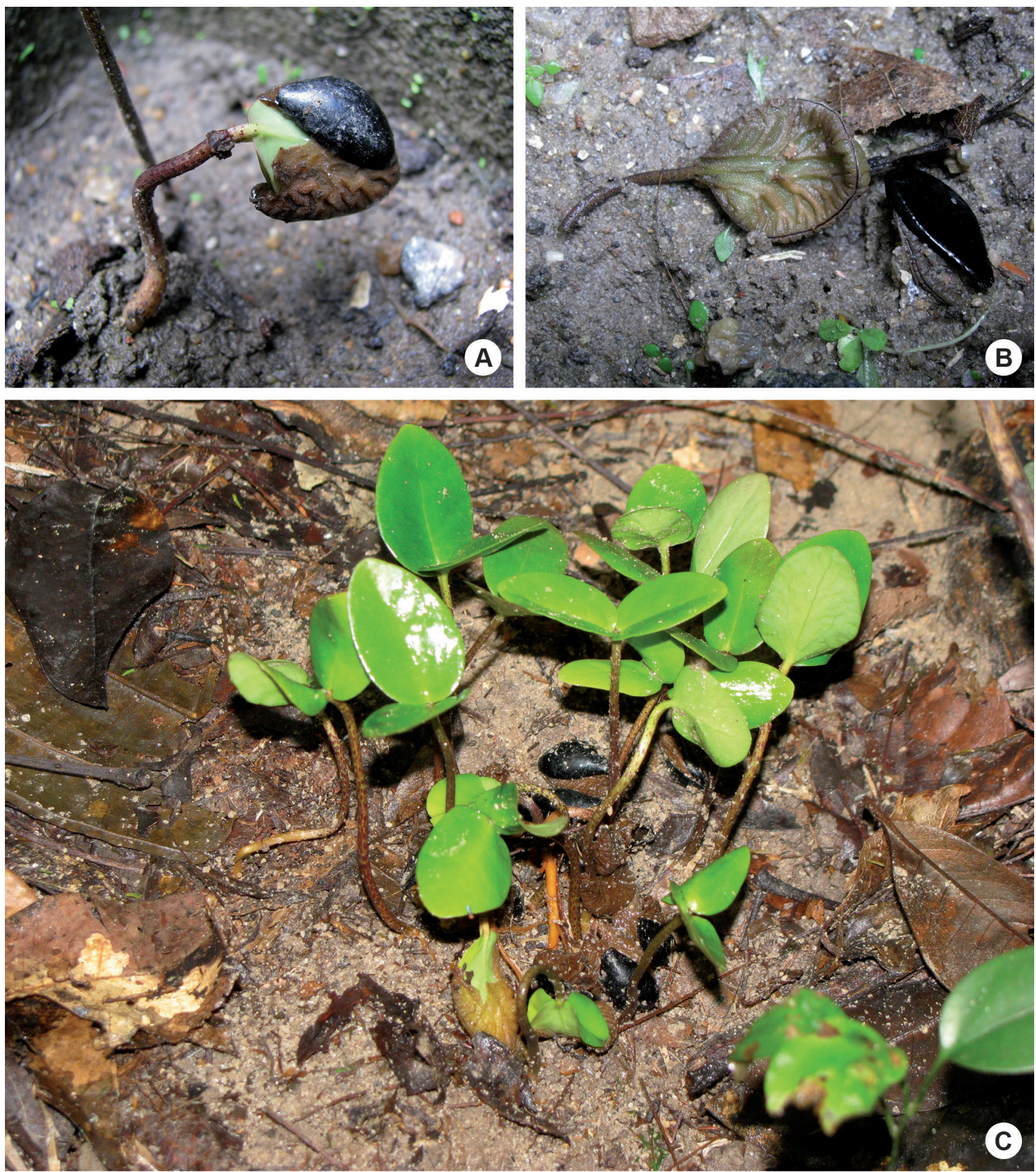

Figure 3. Germination and seedling growth of A. dolichocarpa. A. Germinating seed showing black seed coat (ca. $15 \mathrm{~mm}$ length) and ruminate endosperm partly still covering the cotyledons. B. Size of stretched ruminate endosperm covering the cotyledons relative to black seed coat. C. A group of growing seedlings. One seedling in front still shows the ruminate endosperm before the opening of the cotyledons. Note the small black seed coats on the ground. Photo credit M. Braun. 
observation that seeds of $A$. dolichocarpa take three to eight weeks to germinate (Braun 2010), with the endosperm stretching and covering the cotyledons outside the testa (Figs. 3B-C) warrants further investigation of seedling development in the genus. Apparently, the endosperm takes over the function of protecting and nourishing the growing seedling, since the seed coat is small, hard and unable to expand. It was proposed that the ruminations in the endosperm may enable it to grow by slowly stretching its folds, so that it can still nourish and protect the developing seedling via the cotyledons when the seed coat is already too small to cover it (Braun 2010).

It is likely that in Annonaceae and other families, which have irregular, spiniform or lamelliform endosperm ruminations, these structures protect the embryo and seedling outside the seed coat and accompany the initial growth. By its ability to stretch its folds and to nourish young seedlings during the critical initial consolidation period, ruminate endosperm might be an important support for a successful start and growth of a new plant.

\section{Flowering and fruiting pattern, anthesis and reproductive system}

The flowering of the six species follows two patterns. Four species (A. prinoides, A. crassipetala, A. brevipes, A. manausensis) have the cornucopia (sensu Gentry 1974) or annual (sensu Newstrom et al. 1994) mode of flowering, with a two or three month flower-producing period in the second half of the year, whereas A. phaeocarpa and A. dolichocarpa flowered more or less the whole year long and exhibited the so-called steady state (Gentry 1974) or continuous (Newstrom et al. 1994) flowering mode (Tab. 1). The consequences of the two contrasting flowering modes are differing modes of fruit ripening and seed dispersal periods. For example, A. prinoides, which exhibits the annual mode of flowering and which has its flowering period in September and October, has its fruit ripening mainly during October of the following year (Teichert 2008). The continuous flowering of A. dolichocarpa in the northern Atlantic forests resulted in a more or less continuous fruiting and seed release in this species. There was, however, also in this species a distinct fruiting peak. Most fruits became ripe in the early wet season, i.e. in March, which may be an advantage for seedling establishment (Braun 2010).

All species studied showed a diurnal, two-day lasting, protogynous anthesis. This means that flowers become receptive the first day and shed pollen the second day of flowering, and all further main flower activities, such as opening or dropping of petals, scent production, thermogenesis, floral visitor attraction and release of them happens during daytime. There is, however, quite a variation of anthesis rhythms among different individuals of a species. For example, in A. prinoides, the rare phenomenon of heterodichogamy is acting (Teichert et al. 2011). Within the population of A. prinoides, two morphs having different flowering chronologies occurred (Fig. 4). Of the 19 flowering individuals occurring in the studied population patch, 12 belonged to one phenotypical morph (designated $\mathrm{A}$ ), and seven to the other (B). Individuals of each morph flowered synchronously but in a reciprocal manner to each other. While one morph was in the pistillate stage, the other began the staminate stage. On the first day of anthesis, morph A opened its petals just slightly, forming narrow slits around 9:00 $\mathrm{h}$ and remained in this state without producing any noticeable scent until noon. Around 13:30 h the flowers began to produce a strong banana-like scent, which could be perceived over a distance of several meters, while the stigmatic surface was covered by a colorless exudate. The flowers remained in this pistillate, odoriferous stage throughout the night. At 10:00 h of the second day they changed from the pistillate to the staminate stage, i.e. the anthers opened and pollen was released, which was a period when stigmatic exudates had already dried and floral scent had ceased. During the first part of the staminate stage the petals maintained their semi-closed condition. Around 11:00 $\mathrm{h}$ floral anthesis ended, the petals opened completely and finally dropped. The individuals of the complementary morph B opened their petals slightly around 17:00 h, and remained in this state during the night. The next morning around 9:30 h, precisely one and a half hours before the end of anthesis of morph A, the flowers of morph B, in full pistillate stage, started to emit scent. They changed around 13:00 $\mathrm{h}$ from the pistillate to the staminate stage and the petals dropped at about 14:00 h, half an hour after the new flowers of morph A had started to emit odor. This special mode of induced obligatory change of pollinators and transfer of pollen to other individuals is a way to force cross-pollination.

In $A$. prinoides and the other investigated species, the number of anthetic flowers produced per tree at any moment is low, and often does not exceed one flower per tree. Pollinators leaving such an isolated flower will transfer pollen to the flower of another individual (Webber 1996; Teichert et al. 2011; Braun \& Gottsberger 2011). In $A$. brevipes there is another mechanism for inducing a high probability of cross-pollination. The initiation of the scent-emitting and pollinator-attracting pistillate stage of flowers is not at the same time among flowers of different individuals, and occurred in a staggered way between 7:00 to $12: 30 \mathrm{~h}$. The end of the staminate stage was also staggered in different individual trees and varied from 7:00 to 10:30 h (Webber 1996). Thus, the probability of pollinators changing to another tree individual is enhanced, because other flowers of its proper tree individual are often not in the adequate pollinator-attracting stage when anthesis finishes. The other investigated species have a more coordinated ca. $24 \mathrm{~h}$ flowering rhythm among their individuals, with the initiation of scent in the pistillate 

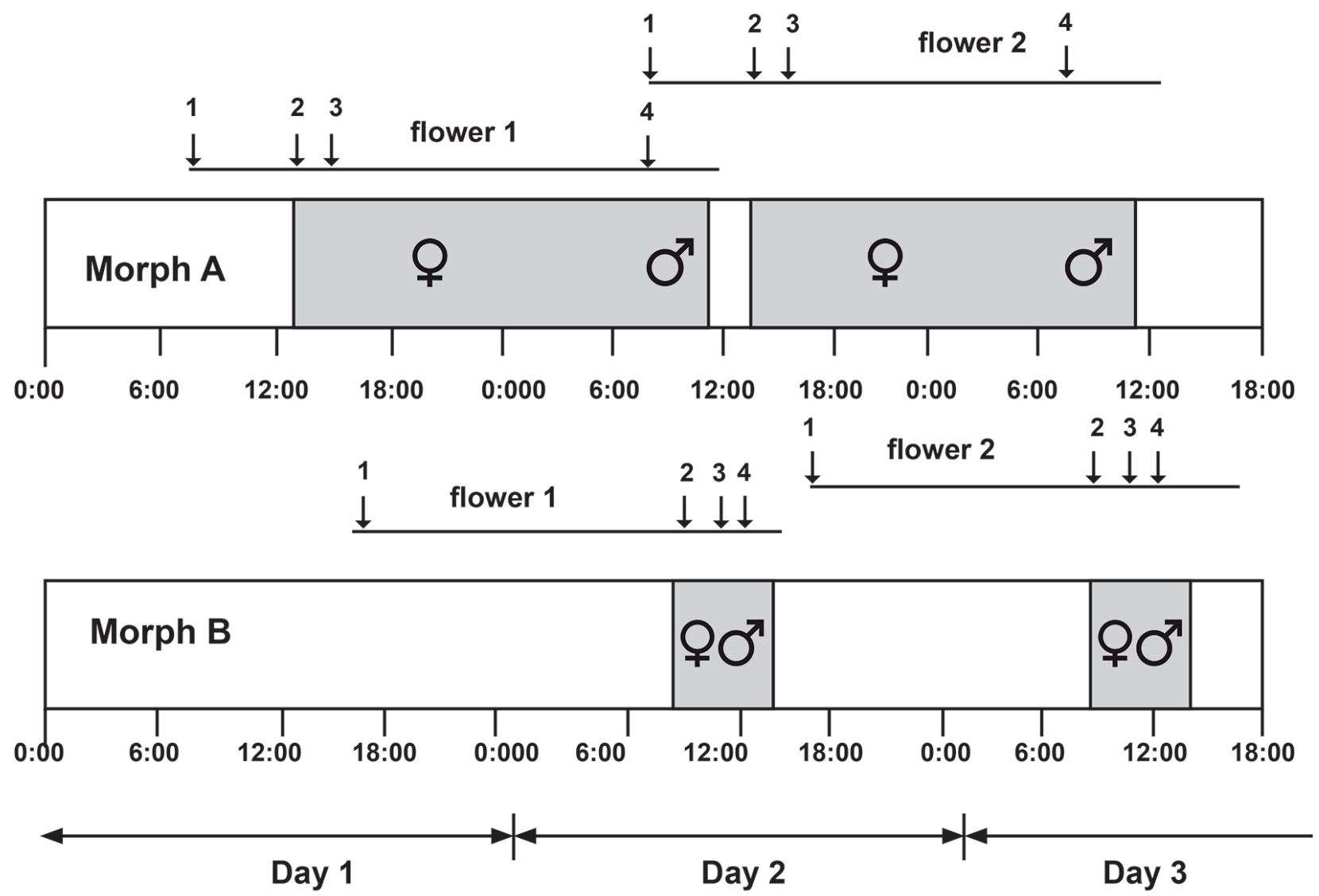

Figure 4. Timing of anthesis of both morphs of A. prinoides: 1 flowers spreading their petals, 2 initiation of scent production, 3 arrival of pollinators, 4 change from pistillate to staminate stage. From Teichert et al. 2011.

stage and the end of anthesis in the staminate stage for all trees in the population at about the same time (Webber 1996; Armstrong \& Marsh 1997; Braun \& Gottsberger 2011). In most Anaxagorea species (with exception of $A$. prinoides) pistillate and staminate stage flowers can occur at the same time on one individual tree. This condition would enable geitonogamous pollination. Self-compatibility was experimentally confirmed in A. crassipetala (Armstrong \& Marsh 1997) and A. dolichocarpa (Braun \& Gottsberger 2011) and is strongly suspected for A. phaeocarpa (Webber 1996) (Tab. 2). However, as explained above, in Anaxagorea there is a strong tendency for effecting cross-pollination, by heterodichogamy in $A$. prinoides, by staggered anthesis rhythms of different individuals in A. brevipes, and a relatively low number of anthetic flowers per individual at any time in other Anaxagorea species.

\section{Thermogenesis and floral scent}

Especially in beetle-pollinated (cantharophilous) flowers, flower temperature may be raised above ambient temperature through metabolic heat production (thermogenesis), resulting in a warm floral or pollination chamber. Thermogenesis does not occur in $A$. prinoides
(Teichert et al. 2011). It was, however, verified in other four species (Webber 1996; Braun \& Gottsberger 2011) (Tab. 2). The temperature elevation, which is mainly produced by the thick petals, in A. brevipes was higher in the pistillate (maximum $1.5^{\circ} \mathrm{C}$ above ambient air) than in the staminate stage ( $\max , 0.9{ }^{\circ} \mathrm{C}$ ). In $\mathrm{A}$. dolichocarpa, thermogenesis was about as high in both stages $\left(\max .3 .8^{\circ} \mathrm{C}\right.$ in pistillate and $\max .3 .7^{\circ} \mathrm{C}$ in staminate stage), while it was higher in the staminate than in the pistillate stage in $\mathrm{A}$. manausensis (max. pistillate stage $4^{\circ} \mathrm{C}$, max. staminate stage $5.5^{\circ} \mathrm{C}$ ) and A. phaeocarpa (max. pistillate stage $2.1^{\circ} \mathrm{C}$, max. staminate stage $4.0^{\circ} \mathrm{C}$ ). Armstrong \& Marsh (1997) found that in A. crassipetala the thick outer petals were composed of starch-bearing parenchyma. Although not measured in this particular species, it is possible to assume that warming of petals in Anaxagorea species is the result of "burning" starch during anthesis. This phenomenon is known from other thermogenic Annonaceae (e.g. Gottsberger et al. 1998 ).

Warming of flowers accelerates scent emission and at the same time it is a "reward" for the flower-visiting beetles (Seymour \& Schultze-Motel 1997; Seymour et al. 2003; 2009; Seymour 2010). In A. prinoides, A. crassipetala and $A$. dolichocarpa, the floral scent had attractive power for floral visitors only during the pistillate stage. In $A$. brevipes, with higher warming in the pistillate than the 
Table 2. Reproductive system, thermogenesis, main floral scent compounds and pollinators of the six investigated Anaxagorea species (data compiled from the authors given in the text).

\begin{tabular}{|c|c|c|c|c|c|c|}
\hline & A. prinoides & A. manausensis & A. brevipes & A. phaeocarpa & A. crassipetala & A. dolichocarpa \\
\hline $\begin{array}{l}\text { Reproductive } \\
\text { system }\end{array}$ & not investigated & not investigated & not investigated & self-compatibility & self-compatibility & self-compatibility \\
\hline Thermogenesis & no & yes & yes & yes & not investigated & yes \\
\hline $\begin{array}{l}\text { Main floral scent } \\
\text { compounds }\end{array}$ & $\begin{array}{l}\text { Ethyl isovalerate, } \\
\text { Isobutyl isovalerate, } \\
\text { Ethyl tiglate } \\
\text { (esters), } \\
\text { Isoamyl alcohol }\end{array}$ & not investigated & $\begin{array}{l}\text { Ethyl 2-methyl- } \\
\text { butanoate, } \\
\text { Isoamyl ethanoate, } \\
\text { (esters), several } \\
\text { other unidentified } \\
\text { esters, } \\
\text { 3-Hexen-1-ol } \\
\text { (alcohol) }\end{array}$ & not investigated & not investigated & $\begin{array}{l}\text { Ethyl 3-methyl- } \\
\text { butanoate, } \\
\text { Isobutyl acetate, } \\
\text { Ethyl 3-hexanoate, } \\
\text { Isobutyl isovalerate } \\
\text { (esters) }\end{array}$ \\
\hline Pollinators & Colopterus spp. & $\begin{array}{l}\text { Colopterus planus, } \\
\text { C. vulneratus, } \\
\text { C. ruptus, } 3 \text { further } \\
\text { Colopterus spp., } \\
\text { Staphylinidae sp. }\end{array}$ & $\begin{array}{l}\text { Colopterus planus, } \\
\text { C. ruptus, } 3 \text { further } \\
\text { Colopterus spp., } \\
\text { Staphylinidae sp. }\end{array}$ & $\begin{array}{l}\text { Colopterus ruptus, } \\
\text { C. vulneratus, } \\
2 \text { further Colopterus } \\
\text { spp. }\end{array}$ & $\begin{array}{l}\text { Nitidulidae } 3 \text { spp., } \\
\text { Staphylinidae sp. }\end{array}$ & Colopterus 3 spp. \\
\hline
\end{tabular}

staminate stage, and in the two other species from Manaus, A. manausensis and A. phaeocarpa, both with higher warming in the staminate than the pistillate stage, floral visitors were attracted in both sexual stages during the first and the second day of anthesis (Webber 1996). The beetles arriving during the staminate phase, at the end of anthesis, augmented the number of individuals carrying pollen to other flowers. In the first case, when beetles were attracted only to pistillate stage flowers, the scent emissions in the staminate phase, e.g. in A. dolichocarpa, had changed and had a slightly more acrid, acetone-like note as compared to the banana-like scent in the initial pistillate stage (Braun \& Gottsberger 2011). In the second case, when beetles were attracted by both, the pistillate and staminate stage flowers, the scent emissions perceived were similar in both stages.

The flowers of Anaxagorea species smell like fruits, namely banana-like in $A$. prinoides and $A$. dolichocarpa, like a mixture of several fruits in A. brevipes, pineapple-, apple- or acetone-like in A. manausensis, and like a mixture of heated jam of Mangifera indica and Theobroma grandiflorum mixed with burned sugar in A. phaeocarpa. It is remarkable that several of the floral scent compounds of the three analyzed Anaxagorea species occur also in fruits (e.g. Wong \& Siew 1994; Fraga \& Rezende 2001; Garruti et al. 2003; Maia et al. 2004). The scent bouquet of $A$. prinoides consists mainly of aliphatic esters, dominated by ethyl isovalerate $(81.7 \%$ of the total volatiles) and followed by isobutyl isovalerate (13.7\%); there is also a small amount of isoamyl alcohol (Teichert et al. 2011). Both main compounds in the floral scent of this species occur also in fruits (see above). In A. brevipes, floral scent compounds contained many esters (dominated by ethyl 2- methylbutanoate, 52.5\%), besides low amounts of the alcohol 3-hexen-1-ol and other compounds (Jürgens et al. 2000). Also the scent of $A$. dolichocarpa was dominated by esters (e.g. ethyl 3-methylbutanoate and isobutyl acetate). Thus, the floral scent of the three analyzed Anaxagorea, with a dominance of esters and additionally alcohols (Tab. 2), occurs also in decaying fruits, which indicates that Anaxagorea flowers with respect to their fragrances are fruit mimics. The three other species, although not yet analyzed with respect to their scent compounds, also smell like fruits, which is a strong hint that they may also mimic fruit scents. The whole spectrum of floral scent compounds in Anaxagorea species, including minor compounds, is given by Goodrich (2012).

\section{Pollinators, flower predators, and the function of the thick-petaled pollination chamber}

The pollinators of Anaxagorea species studied so far are primarily Nitidulidae (2-5 mm long) (Fig. 5) and in much lower abundance also Staphylinidae (ca. $2 \mathrm{~mm}$ long). In the five South American species, the nitidulid beetles could be identified to genus and in some cases even to species level (Webber 1996; Braun \& Gottsberger 2011; Teichert et al. 2011). They all belong to the genus Colopterus, with up to six different species visiting the flowers of one Anaxagorea species (Tab. 2). Colopterus spp. are not host specific, visiting several sympatric Annonaceae species belonging to Anaxagorea, Duguetia and Guatteria in Central Amazonia (Webber 1996). In fact, they are probably independent of 
The reproductive biology of the early-divergent genus Anaxagorea (Annonaceae),

and its significance for the evolutionary development of the family
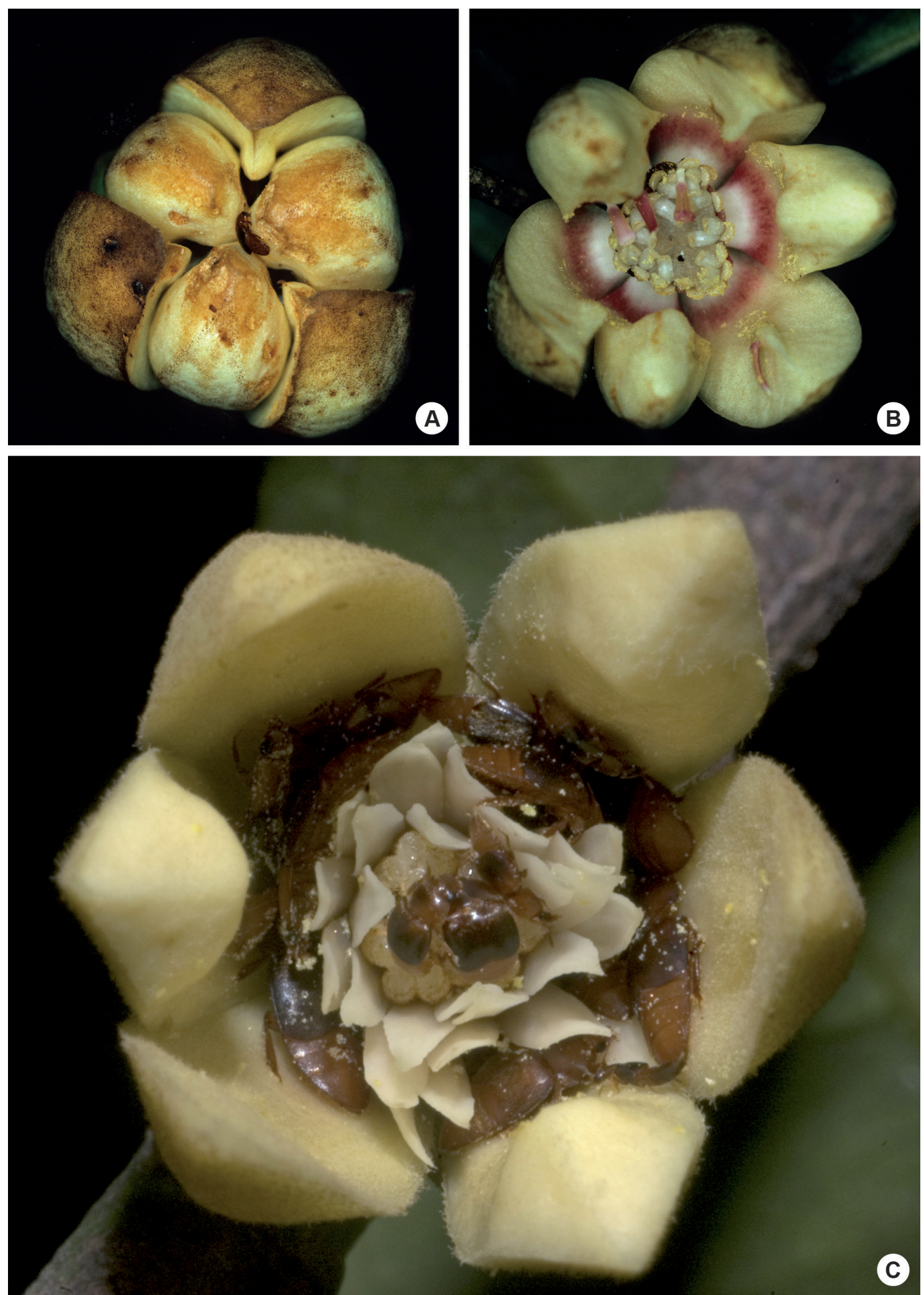

Figure 5. Flowers of A. brevipes. A. Flower in pistillate stage with closed petals (length of petals ca. $20 \mathrm{~mm}$ ), forming a pollination chamber. A Colopterus beetle is visible before entering the interior of the flower via the small openings between the petal tips. B. Flower in the staminate stage with open petals. Colopterus beetle is visiting the stamens with dehisced anthers. Photo credit A.C. Webber. C. A. prinoides flower (petal length ca. $10 \mathrm{~mm}$ ) during the staminate stage, crowded with smaller and larger Colopterus beetles dusted with pollen. Photo credit H. Teichert. 


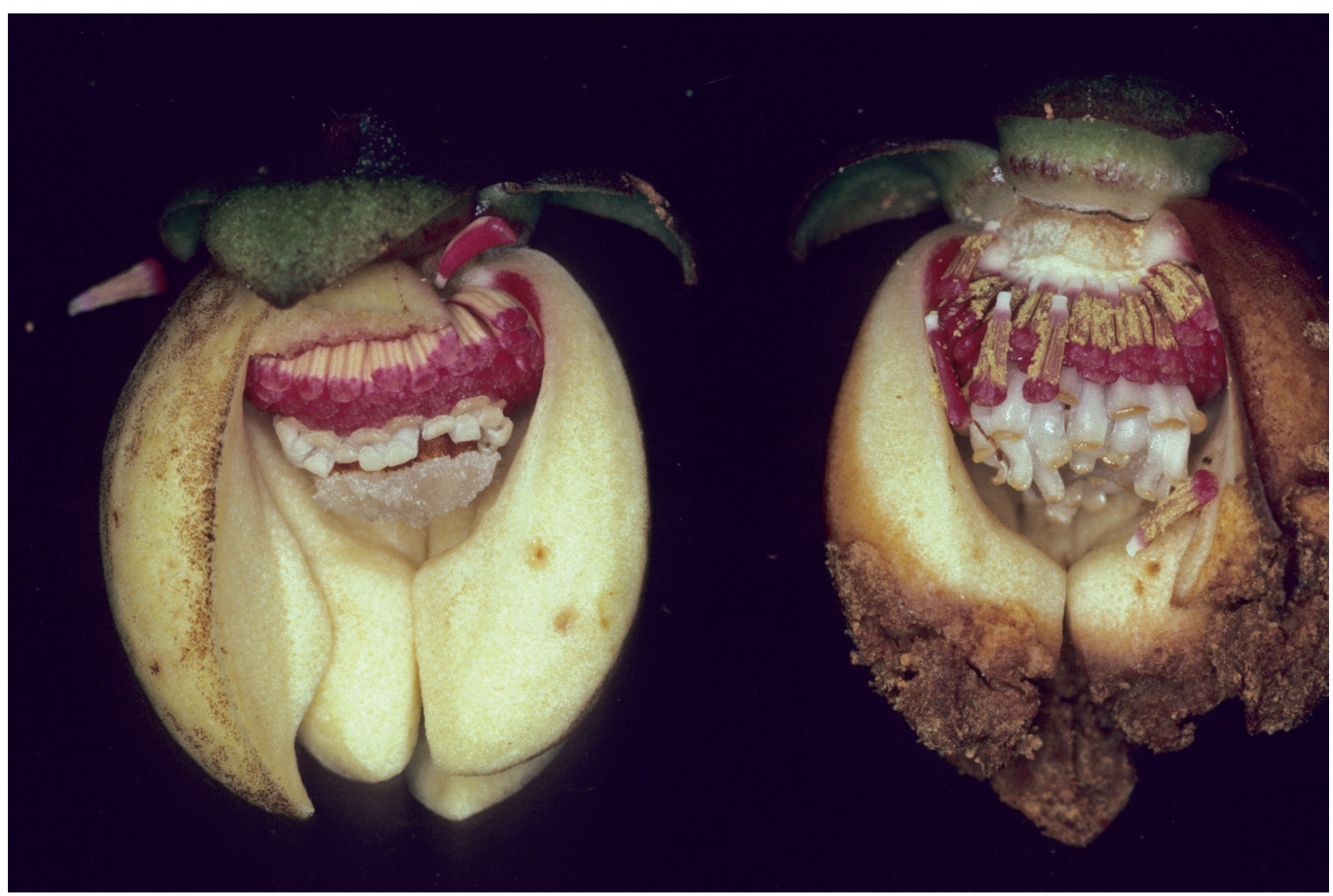

Figure 6. Two flowers of A. brevipes (length of petals ca. $20 \mathrm{~mm}$ ) with some petals removed, showing the reproductive organs inside the pollination chamber. Left flower in pistillate stage with receptive stigmas. The white inner staminodes (between the still closed stamens and the stigmas) are inclined towards the stamens. Right flower in staminate stage with stamens having dehisced anthers. The elongated white staminodes are erect and partly cover the non-receptive stigmas. Photo credit A.C. Webber.

floral resources for survival, as Colopterus spp. were regularly found foraging on decaying fruits (Gottsberger 1970; Williams \& Salles 1986). Thus, in case of Colopterus spp. it was early suggested (Gottsberger 1970) that these fruiteating beetles are deviated from their "normal" substrate, decaying fruits, by fleshy, fruit-like smelling Annonaceae flowers, which they are visiting and thus becoming their pollinators.

Some Anaxagorea species have glandular areas at the apex of the inner staminodes. Scharaschkin \& Doyle (2006) were wondering about the role of these characteristics in pollination. Neither in A. phaeocarpa (Webber 1996) and A. dolichocarpa (Braun \& Gottsberger 2011), which have these glandular areas, nor in the other four species, which do not have glands, were any marks of gnawing on the staminodes nor on the fleshy petals noted. The staminodial glands and probably also the stigmatic exudates may be licked by the beetles after entering the pistillate stage flowers. However, the closed pollination chamber during this stage make direct observations of the small beetles difficult. The staminodes themselves make movements during anthesis (Webber 1996; Braun \& Gottsberger 2011) (Fig. 6). In the pistillate stage, they spread and incline towards the stamens, such that beetles penetrating the pollination chamber are canalized towards the region of the carpels with receptive stigmas. During the staminate stage the staminodes incline towards the carpels, sometimes growing a bit and becoming longer and then they even partly cover the stigmas. This makes the way free for the beetles to crawl down to the opening stamens and to eat pollen. As some species attract their pollinators in the pistillate and staminate stages, the beetles arriving in the staminate stage are not impeded by erect staminodes and can crawl directly to the stamens. Thus, the movement of the staminodes largely keeps the beetles during the pistillate stage in the pistillate region of the flower, while the staminodes during the staminate stage make the way free for the beetles to penetrate further down into the pollination chamber to the region of the stamens. Through this herkogamous mechanism, the beetles are always being concentrated in the right compartment of the pollination chamber, initially on the pistils, where they can deposit pollen sticking on them, and later on the dehisced stamens, where they may receive a new pollen load before leaving the flower. 
Colopterus species and Staphylinidae penetrate the dark, scent-emitting pollination chamber and thus effect pollination (Fig. 5). However, there are other groups of insects which are also regular visitors of Anaxagorea flowers, but which because of their size and behavior remain just outside the flowers without penetrating its interior. Common visitors are weevils (Curculionidae), Chrysomelidae and flies (Drosophilidae), which gnaw on the thick petals, or their larvae are petal or ovule predators (e.g. Webber 1996; Armstrong \& Marsh 1997; Collier \& Armstrong 2009). The flowers and the thick petals are thus also a floral brood substrate used in a regular way (florivory) as many insects use other ephemeral substrates, like carrion, dung, fruits and fungi (e.g. Grimaldi \& Engel 2005). In the light of these findings, the thick petals of Anaxagorea may be interpreted also as antipredator structures. With their abundant and thick excess tissue they diminish the effect of predation on reproduction. There are further functions of the petals which may explain their remarkable and unusual thickness (thick even when compared with other Annonaceae; see, e.g. Scharaschkin \& Doyle 2006; Collier \& Armstrong 2009). The petals form a closed and dark pollination chamber which emits strong fruit-like scent compounds, enticing the fruit beetles to enter the floral chamber (Fig. 5). Another function of the thick petals in many species is the production of heat, as described earlier, which enhances scent emission and provides a warm shelter for the attracted beetles. For producing heat, a flower or inflorescence has to have thick tissues to be able to accumulate the large amounts of starch or occasionally also lipids necessary to accelerate intense heat-producing respiratory processes (e.g. Gottsberger et al. 1998).

\section{Character states and developments in Anaxagorea and a comparison with other Annonaceae}

Among the six species investigated, A. prinoides has the smallest flowers, with the shortest petals (ca. $11 \mathrm{~mm}$ length), the lowest number of stamens (ca. 14), staminodes (ca. 11) and carpels (ca. 12) (Tab. 1). Small flowers, with relatively short petals and a low number of floral parts occur in several other Neotropical Anaxagorea species, notably in A. angustifolia, A. brevipedicellata, A. floribunda, and A. pachypetala, and the Asian species A. borneensis and A. luzonensis (Maas \& Westra 1984; 1985). Small flower size and a relatively low number of reproductive organs and staminodes are probably correlated with each other because smaller flowers have a relatively shorter floral axis and can bear only few organs. On the other hand, it will be interesting to see if other species with small-sized flowers are also non-thermogenic.

In the genus Anaxagorea, a series of flower morphological variations, developments or evolutionary shifts can be observed (Maas \& Westra 1984; 1985; Maas et al. 1986; Scharaschkin \& Doyle 2006). For example, a more roundish floral bud form seems to be basic in the genus, while conical buds are an important character principally of the Central American clade and only of one species of the South American clade. Together with the conical bud form, species of the Central American clade have inner petals that are conspicuously shorter than the outer petals. While the presence of two whorls of petals is ancestral for Anaxagorea and for Annonaceae as a whole, the inner whorl was lost independently in the two Asian taxa A. borneensis and a variety of $A$. javanica. Valvate petals are ancestral for the genus, but one species, $A$. silvatica, has outer imbricate petals. In this species and in A. javanica var. dipetala the perianth is dimerous instead of being trimerous. Besides the very fleshy petals in all Anaxagorea species, many species have a conspicuous keel on the inner petals (ancestral character) while others have bowl-shaped petals without this protrusion (being considered as derived). Most species have inner staminodes (ancestral), but two species, the South American A. pedicellata and the Asian A. luzonensis lack inner staminodes, which are considered to be independent losses within Anaxagorea. A relative low number of staminodes (up to 20) seems to be ancestral, while a number above 20 is typical for a larger (derived) part of the core South American group. Most Anaxagorea species have more or less laminar stamens, assumed to be ancestral, while some species show deviations with stamens that approach the peltate type. A very high number of stamens (more than 100) is a derived character uniting three species in the core American clade, A. brachycarpa, A. rufa and A. brevipes. "The ancestral shape of the stamen apex in Anaxagorea was pointed, as in most of the outgroups, but in the basal species $A$. prinoides there was an early shift to rounded stamens with some reversals to pointed stamens" (Scharaschkin \& Doyle 2006). There are many more generative and vegetative character states, which indicate the character evolution in the genus. It is assumed, that several distinctive similarities between Anaxagorea and other Magnoliales are primitive retentions. Also a number of morphological derived character states have been identified for the clades containing on the one side most Central American species and on the other side all Asian species (Scharaschkin \& Doyle 2006).

The understanding of evolution of the character states in Anaxagorea provides insights in the capacity and great plasticity of this basal genus. Anaxagorea certainly has been an evolutionary active group. This is documented by the many morphological variations and modifications in different species and clades. With regard to its morphological variations and reproductive biology, Anaxagorea is important for understanding several floral and functional traits in the rest of the family.

Some characteristics of the early-divergent genus Anaxagorea (subfam. Anaxagoreoideae), such as inner 
staminodes, were lost in the three derived subfamilies. Valvate (ancestral state) and imbricate petals (derived state) as in Anaxagorea occur also in the rest of the family. The same happens with trimerous and dimerous flowers or with thick fleshy petals. Many species of the rest of the family also exhibit thermogenesis (especially beetle-pollinated ones) and produce scent emissions which are either fruitlike or otherwise strong smelling. Some derived Annonaceae maintain the pointed or rounded prolongation of the connective, however, in most Annonaceae this connective is modified and transformed into a hard connective shield, which, together with the thick petals is interpreted as an antipredator structure in the mainly beetle-pollinated family (Gottsberger 2012).

Probably more than $90 \%$ of all Annonaceae species are beetle-pollinated (Gottsberger 2012), but different lines of cantharophily have evolved: pollination by small beetles, mainly by Nitidulidae, Staphylinidae, Curculionidae, Chrysomelidae, with a body length up to $7 \mathrm{~mm}$, versus pollination by large beetles (Scarabaeidae, subfamilies Dynastinae, Rutelinae, Cetoniinae, Trichiinae, body length 14-22 $\mathrm{mm}$ ), diurnally versus nocturnally active flowers, and flowers with thermogenesis (especially notable in nocturnal species). Other lines of specialization are evident in the few species pollinated by thrips (Thysanoptera), cockroaches, flies and bees. A more or less closed pollination chamber as in cantharophilous flowers would be an obstacle for flies, bees and cockroaches trying to reach the reproductive organs of flowers. As an adaptation to these "free working" pollinators, the myiophilous, melittophilous or cockroachpollinated Annonaceae have open flowers with reflexed petals which gives pollinators free access to the flower center. Small and elongate thrips do not need an open flower to penetrate into its center, and flowers pollinated by these insects are either closed or semiclosed (Gottsberger 2012). As in cantharophilous flowers, non-cantharophilous flowers, that occur in species of the derived groups, the two large sister clades, subfamilies Annonoideae and Malmeoideae (Chatrou et al. 2012), have characteristics related to the behavior and senses of their respective pollinating insects. Notwithstanding, non-cantharophilous species often retain one or more cantharophilous associated characters, e.g. thick, fleshy petals, flattened and sclerified connective shields, or protogynous dichogamy (Gottsberger 2012).

\section{Acknowledgements}

Many thanks to my wife Ilse Silberbauer-Gottsberger for her help with the literature and for reading and improving the manuscript, and to Graciela Hintze for elaborating the figures. Antonio C. Webber, Holger Teichert and Marcus Braun kindly provided photographs. Two anonymous reviewers were helpful with several English edits, corrections and suggestions to improve the manuscript.

\section{References}

Armstrong JE, Marsh D. 1997. Floral herbivory, floral phenology, visitation rate, and fruit set in Anaxagorea crassipetala (Annonaceae), a lowland rain forest tree of Costa Rica. Journal of the Torrey Botanical Society 124: 228-235.

Bayer C, Appel O. 1996. Occurrence and taxonomic significance of ruminate endosperm. The Botanical Review 62: 301-310.

Berry PE, Miller RB, Wiedenhoeft AC. 1999. A new lightweight-wooded species of Anaxagorea (Annonaceae) from flooded black-water shrublands in southern Venezuela. Systematic Botany 24: 506-511.

Braun M. 2010. Floral biology, breeding system, pollination and reproductive success of selected understory tree species in fragments of Atlantic rainforest in Pernambuco, Brazil. PhD Thesis, University of Ulm, Germany.

Braun M, Gottsberger G. 2011. Floral biology and breeding system of Anaxagorea dolichocarpa (Annonaceae), with observations on the interval between anthesis and fruit formation. Phyton (Horn, Austria) 51: 315-327.

Braun M, Gottsberger G. 2012. Reproduction of beetle-pollinated Anaxagorea dolichocarpa (Annonaceae) is resilient to habitat disturbance in rainforest fragments. Nordic Journal of Botany 30: 453-460.

Bremer B, Bremer K, Chase MW, et al. 2009. An update of the Angiosperm Phylogeny Group classification for the orders and families of flowering plants: APG III. Botanical Journal of the Linnean Society 161: 105-121.

Chatrou LW, Pirie MD, Erkens RHJ, et al. 2012. A new subfamilial and tribal classification of the pantropical flowering plant family Annonaceae informed by molecular phylogenetics. Botanical Journal of the Linnean Society 169: 5-40.

Collier GE, Armstrong JE. 2009. Sequential florivory/saproflorivory of Anaxagorea crassipetala (Annonaceae) by Diathoneura tessellata (Drosophilidae). Annals of the Entomological Society of America 102: 492-497.

Corner EJH. 1949. The annonaceous seed and its four integuments. New Phytologist 48: 332-364.

Doyle JA, Bygrave P, Le Thomas A. 2000. Implications of molecular data for pollen evolution in Annonaceae. In: Harley MM, Morton CM, Blackmore S. (eds.) Pollen and Spores: Morphology and Biology. Kew, Royal Botanic Gardens. p. 259-284.

Doyle JA, Le Thomas A. 1994. Cladistic analysis and pollen evolution in Annonaceae. Acta Botanica Gallica 141: 149-170.

Doyle JA, Le Thomas A. 1996. Phylogenetic analysis and character evolution in Annonaceae. Bulletin du Muséum National d'Histoire Naturelle, section $B, 18:$ 279-334.

Fraga SRG, Rezende CM. 2001. The aroma of the Brazilian ambarella fruit (Spondias cytherea Sonnerat). Journal of Essential Oil Research 13: 252-255.

Garruti DS, Franco MRB, Silva MAAP, Janzantti NS, Alves GL. 2003. Evaluation of volatile flavour compounds from cashew apple (Anacardium occidentale L.) juice by the osme gas chromatography/ olfactometry technique. Journal of the Science of Food and Agriculture 83: 1455-1462.

Gentry AH. 1974. Flowering phenology and diversity in tropical Bignoniaceae. Biotropica 6: 64-68.

Goodrich KR. 2012. Floral scent in Annonaceae. Botanical Journal of the Linnean Society 169: 262-279.

Gottsberger G. 1970. Beiträge zur Biologie von Annonaceen-Blüten. Österreichische Botanische Zeitschrift 118: 237-279.

Gottsberger G. 1978. Seed dispersal by fish in the inundated regions of Humaitá, Amazonia. Biotropica 10: 170-183.

Gottsberger G. 2012. How diverse are Annonaceae with regard to pollination? Botanical Journal of the Linnean Society 169: 245-261.

Gottsberger G, Webber AC, Hildenbrand M. 1998. Nutritious tissues in Annonaceae flowers. In: Westra LYTh. (ed.) Annonaceae Newsletter, Utrecht, 12: 25-26.

Grimaldi D, Engel MS. 2005. Evolution of the Insects. New York, Cambridge University Press. 


\section{The reproductive biology of the early-divergent genus Anaxagorea [Annonaceae], and its significance for the evolutionary development of the family}

Jürgens A, Webber AC, Gottsberger G. 2000. Floral scent compounds of Amazonian Annonaceae species pollinated by small beetles and thrips. Phytochemistry 55: 551-558.

Kessler PJA. 1993. Annonaceae. In: Kubitzki K, Rohwer JG, Bittrich V. (eds.) The Families and Genera of Vascular Plants II. Berlin, Heidelberg, New York, Springer. p. 93-128.

Maas PJM, Westra LYTh. 1984. Studies in Annonaceae. II. A monograph of the genus Anaxagorea A. St. Hil. Part 1. Botanische Jahrbücher für Systematik 105: 73-134.

Maas PJM, Westra LYTh. 1985. Studies in Annonaceae. II. A monograph of the genus Anaxagorea A. St. Hil. Part 2. Botanische Jahrbücher für Systematik 105: 145-204.

Maas PJM, Westra LYTh, Koek-Noorman J. 1986. Studies in Annonaceae. V. Additional notes on Anaxagorea A. St. Hil. Proceedings of the Koninklijke Nederlandse Akademie van Wetenschappen 89: 75-82.

Maas-van de Kamer H. 1993. Floral biology of Anaxagorea dolichocarpa, and some notes on flower biology of Annonaceae. In: Westra LYTh. (ed.) Annonaceae Newsletter 9. Utrecht, Utrecht University. p. 19-24.

Maia JGS, Andrade EHA, Zoghbi MGB. 2004. Aroma volatiles from two fruit varieties of jackfruit (Artocarpus heterophyllus). Food Chemistry 85: 195-197.

Morawetz W. 1984. Karyological races and ecology of the Brazilian Duguetia furfuracea as compared with Xylopia aromatica (Annonaceae). Flora 175: 195-209.

Newstrom LE, Frankie GW, Baker HG. 1994. A new classification for plant phenology based on flowering patterns in lowland tropical rain forest trees at La Selva, Costa Rica. Biotropica 26: 141-159.

Pirie MD, Doyle JA. 2012. Dating clades with fossils and molecules: the case of Annonaceae. Botanical Journal of the Linnean Society 169: 84-116.

Sauquet H, Doyle JA, Scharaschkin T, Borsch T, Hilu KW, Chatrou LW, Le Thomas A. 2003. Phylogenetic analysis of Magnoliales and Myristicaceae based on multiple data sets: implications for character evolution. Botanical Journal of the Linnean Society 142: 125-186.

Scharaschkin T, Doyle JA. 2005. Phylogeny and historical biogeography of Anaxagorea (Annonaceae) using morphology and non-coding chloroplast sequence data. Systematic Botany 30: 712-735.

Scharaschkin T, Doyle JA. 2006. Character evolution in Anaxagorea (Annonaceae). American Journal of Botany 93: 36-54.
Seymour RS. 2010. Scaling of heat production by thermogenic flowers: limits to floral size and maximum rate of respiration. Plant Cell and Environment 33: 1474-1485.

Seymour RS, Schultze-Motel P. 1997. Heat-producing flowers. Endeavour 21: $125-129$

Seymour RS, White CR, Gibernau M. 2003. Heat reward for insect pollinators. Nature 426: 243-244.

Seymour RS, White CR, Gibernau M. 2009. Endothermy of dynastine scarab beetles (Cyclocephala colasi) associated with pollination biology of a thermogenic arum lily (Philodendron solimoesense). Journal of Experimental Biology 212: 2960-2968.

Smith SA, Beaulieu JM, Donoghue MJ. 2010. An uncorrelated relaxed-clock analysis suggests an earlier origin for flowering plants. Proceedings of the National Academy of Science of the United States of America 107: 5897-5902.

Teichert H. 2008. Pollination biology of cantharophilous and melittophilous Annonaceae and Cyclanthaceae in French Guyana. PhD Thesis, University of Ulm, Germany.

Teichert H, Dötterl S, Gottsberger G. 2011. Heterodichogamy and nitidulid beetle pollination in Anaxagorea prinoides, an early divergent Annonaceae. Plant Systematics and Evolution 291: 25-33.

Webber AC. 1996. Biologia floral, polinização e aspectos fenológicos de algumas Annonaceae na Amazônia Central. PhD Thesis, Instituto Nacional de Pesquisas da Amazônia e Fundação Universidade do Amazonas, Brazil.

Webber AC, Gottsberger G. 1994. Biologia floral e polinização de Anaxagorea brevipes. VI. Congreso Latinoamericano de Botanica, Mar del Plata, Argentina. Resúmenes: 851.

Williams RN, Salles LAB. 1986. Nitidulidae associated with fruit crops in Rio Grande do Sul, Brazil. Florida Entomologist 69: 298-302.

Wong KC, Siew SS. 1994. Volatile components of the fruits of bambangan (Mangifera indica Kostermans) and binjai (Mangifera caesia Jack). Flavour and Fragrance Journal 9: 173-178.

Zeng L, Zhang Q, Sun R, Kong H, Zhang N, Ma H. 2014. Resolution of deep angiosperm phylogeny using conserved nuclear genes and estimates of early divergence times. Nature Communications doi 10.1038/ncomms5956: 1-12.

Zuilen CMV, Koek-Noorman J. 1997. Phylogenetic relationships within the Annonaceae: molecules and morphology. In: Westra LYTh. (ed.) Annonaceae Newsletter 11. Utrecht, Utrecht University. p. 67-70. 